\title{
Penggunaan Aplikasi Google Meet dalam Menunjang Keefektifan Belajar Daring Masa Pandemi Covid-19 di SMA Negeri 3 Pekanbaru
}

\author{
Piki Setri Pernantah ${ }^{1}$, Nova $^{2}$, Annisa Suci Ramadhani ${ }^{3}$ \\ ${ }^{1,3}$ Universitas Riau \\ ${ }^{3}$ SMA Negeri 3 Pekanbaru \\ * e-mail: piki.setri@lecturer.unri.ac.id
}

\begin{abstract}
Expected online learning can run well; teachers are expected to take advantage of technology in their learning. One of the uses of technology is using learning application media. At SMA Negeri 3 Pekanbaru, they have used the Google Meet application, Google Classroom, and Whatsapp in the online learning process. SMA Negeri 3 Pekanbaru teachers are more likely to use the Google Meet application in online learning from several observations in the field. The Google Meet application is considered to be easier and more effective in delivering learning material. This study aims to describe the perceptions of students and teachers and the process of using the Google Meet application in online learning at these schools. This type of research is qualitative research with a descriptiveanalysis approach. Based on field research, it is known that the Google Meet application is classified as more effective than other learning application media. The use of Google Meet, which is of interest to students and teachers, certainly supports effective online learning during the COVID-19 pandemic.
\end{abstract}

Keywords: google meet, online learning, learning effectiveness

(1) Licensees may copy, distribute, display and perform the work and make derivative works and remixes based on it only if they give the author or licensor the credits (attribution) in the manner specified by these. Licensees may copy, distribute, display, and perform the work and make derivative works and remixes based on it only for non-commercial purposes.

\section{INTRODUCTION}

Bencana pandemi Covid-19 telah menimbulkan dampak pada berbagai bidang, salah satu yang paling dirasakan adalah bidang pendidikan. Mulai dari pendidikan dasar hingga pendidikan tinggi, semuanya menjadi terhambat dan tidak bisa dilaksanakan secara tatap muka karena kerumunan dapat memperluas penyebaran virus Covid-19. Mendikbud RI Nadiem Makarim mengatakan bahwa kondisi Pandemi Covid-19 tidak memungkinkan kegiatan belajar mengajar berlangsung secara normal. Menanggapi situasi demikian, Kementrian Pendidikan dan Kebudayaan mengeluarkan Surat Edaran No. 4 Tahun 2020 tentang Pelaksanaan Kebijakan Pendidikan dalam Masa Darurat Penyebaran Covid-19 yang dilaksanakan secara daring atau pembelajaran jarak jauh (PJJ).
Perubahan sistem pembelajaran dari luring (offline) menjadi daring (online) tentu saja tidak terlepas dari beberapa kendala yang dihadapi seperti ketidak siapan siswa terhadap perubahan sistem pembelajaran ini. Dilansir dari website www.kemdikbud.go.id, dapat diketahui bahwa banyak kendala yang dihadapi guru dan siswa selama pembelajaran jarak jauh (daring). Terdapat beberapa kendala yang dihadapi guru, yakni: a) Guru kesulitan mengelola PJJ dan cenderung fokus pada penuntasan kurikulum; b) Waktu pembelajaran berkurang sehingga guru tidak mungkin memenuhi beban jam mengajar; c) Guru kesulitan komunikasi dengan orang tua sebagai mitra di rumah. Sedangkan kendala yang dihadapi oleh siswa, yakni: a) Siswa kesulitan konsentrasi belajar dari rumah dan mengeluhkan beratnya penugasan soal dari guru; b) Peningkatan rasa stress dan jenuh 
akibat isolasi berkelanjutan berpotensi menimbulkan rasa cemas dan depresi bagi siswa.

Kendala lain yang juga dihadapi adalah pembelajaran melalui internet menjadi hal yang cukup sulit dilakukan di beberapa daerah tertentu dengan jaringan yang kurang memadai. Penggunaan kuota internet juga memunculkan pengeluaran biaya baru yang bisa menjadi masalah bagi beberapa siswa yang mengalami kesulitan finansial [1]. Kondisi tersebut menuntut guru untuk dapat melakukan inovasi dalam proses pembelajaran masa pandemi ini, khususnya pembelajaran melalui daring [2].

Inovasi pembelajaran daring yang dilaksanakan masa pandemi ini tidak dapat dilepaskan dengan bantuan teknologi (aplikasi) pembelajarang yang mulai trend digunakan di era saat ini. Beberapa bentuk media aplikasi pembelajaran daring yang dapat dimanfaatkan adalah Google Meet, Google Classroom, WhatsApp dan sebagainya. Media aplikasi pembelajaran yang paling direkomendasikan tentunya dapat mendukung interaksi antara guru dan siswa secara efektif. Dimana proses pembelajaran dapat dilakukan melalui video conference, yang tidak hanya berinteraksi secara audio tetapi juga dapat bertatap muka meskipun tidak secara langsung, istilah sekarang "bertatap layar".

Salah satu media aplikasi untuk melakukan video conference yaitu aplikasi Google Meet. Google Meet ini memungkinkan guru dan siswa untuk melakukan panggilan secara audiovisual dalam bentuk klasikal atau dalam jumlah banyak orang. Selain itu, aplikasi ini menyediakan banyak fitur yang dapat mendukung pelaksanaan pembelajaran secara daring. Pembelajaran online dengan memanfaatkan Google Meet mempermudah guru dalam memaparkan materi pembelajaran dan membangun kelas yang aktif-kreatif dengan banyak berinteraksi dan berdiskusi dengan siswa maupun antar siswa. Sehingga tidak menutup peluang bahwa proses pembelajaran dapat efektif dilaksanakan meskipun secara daring.

Penelitian ini dilakukan dengan tujuan mendapatkan informasi bagaimana persepsi guru dan siswa terhadap penggunaan Google Meet pada proses pembelajaran online. Apakah aplikasi Google Meet ini menjadi aplikasi yang efektif untuk pembelajaran online di SMAN 3 Pekanbaru, sehingga dapat menjadi evaluasi bagi sekolah (terutama guru) saat akan memilih aplikasi pembelajaran daring.

Pembelajaran daring (dalam jaringan) adalah pembelajaran yang dilakukan secara online, menggunakan aplikasi pembelajaran maupun jejaring sosial [3]. Sehingga pembelajaran era digital (daring) ini dapat menjadi lebih efektif dengan menggunakan bantuan teknologi [4]. Salah satu teknologinya adalah Google Meet. Dengan adanya pandemi Covid-19, Google Meet menjadi salah satu layanan Google yang mengalami pertumbuhan tercepat, dimana angka penggunanan hariannya meningkat signifikan di tahun 2020 ini [5]. Google Meet merupakan media layanan komunikasi video yang dikembangkan oleh Google LLC, sebuah perusahaan multinasional Amerika Serikat yang berkekhususan pada jasa dan produk Internet. Google Meet menjadi salah satu media pembelajaran yang dapat dipakai untuk menumbuhkan rasa kreatifitas guru dalam mengembangkan media pembelajaran dengan menggunakan aplikasi. Aplikasi ini adalah salah satu aplikasi Google yang dapat menunjang pembelajaran daring [6]. Google Meet merupakan aplikasi ke dua terpopuler yang digunakan dalam pembelajaran daring [7]. Dimana tengah populernya penggunaan aplikasi Google Meet ini tentunya juga berdampak pada pelaksanaan proses pembelajaran agar lebih efektif.

\section{If Google Meet}

Gambar 1. Logo Google Meet Sumber : wikipedia.org 


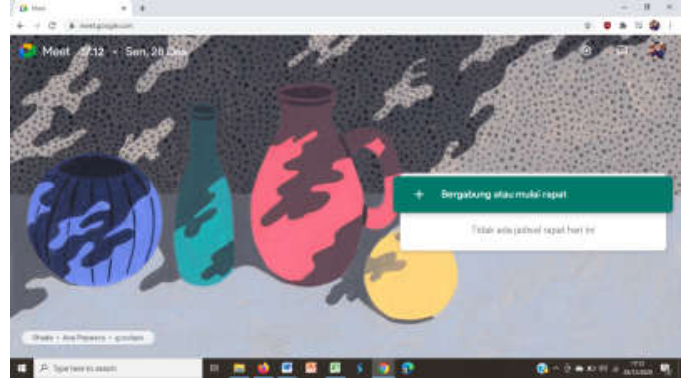

Gambar 2. Halaman Utama Google Meet Sumber : Dokumen Pribadi

Keefektifan belajar adalah satu standar mutu pendidikan dan sering kali diukur dengan tercapainya tujuan, yang diperoleh setelah pelaksanaan proses belajar mengajar, yang menyediakan kesempatan belajar sendiri atau melakukan aktivitas seluas-luasnya kepada siswa untuk belajar [8]. Efektivitas pembelajaran dapat tercapai, salah satunya dengan menggunakan media dalam proses pembelajaran yang sesuai dengan situasi dan kondisi, baik dari konten materi ataupun keadaan lingkungan siswa [9]. Meskipun terjadi perubahan pembelajaran dari tatap muka ke tatap layar, maka pembelajaran daring yang dilakukan saat ini harus diupayakan untuk terus efektif.

Dalam proses pembelajaran daring maka penggunaan video conference sangat dibutuhkan agar guru dan siswa walaupun jaraknya berjauhan masih dapat secara langsung berkomunikasi [10]. Pembelajaran daring dengan menggunakan aplikasi Google Meet dikategorikan sebagai pembelajaran daring yang bersifat synchronous, yakni pembelajaran daring secara langsung [11].

\section{METHODS}

Metode penelitian mengacu pada prosedur tertentu untuk mengumpulkan dan menganalisis data [12]. Metode penelitian ini adalah penelitian kualitatif dengan menggunakan pendekatan deskriptif-analisis. Penelitian kualitatif berarti proses eksplorasi dan memahami makna perilaku individu dan kelompok dalam sebuah fenomena, kasus, isu, dan sebagainya [13]; [14]; [15].

Data yang dikumpulkan secara triangulasi data melalui hasil observasi lapangan, wawancara, survey, dan studi dokumentasi di SMA Negeri 3 Pekanbaru. Data dianalisis dengan paradigma induktif yang berupaya memahami makna dan persepsi tentang pentingnya penggunaan aplikasi ini, serta mengkontruksi fenomena pembelajaran daring di SMA Negeri 3 Pekanbaru. Dalam penyajian datanya digunakan dua metode yaitu dalam bentuk diagram dan deskriptif. Diagram bertujuan untuk memudahkan pembaca dalam melihat hasil dengan cepat dan sistematis. Sedangkan deskripsi akan menerangkan secara lebih detail diagram yang disajikan sekaligus pembahasannya.

\section{FINDING AND DISCUSSIONS}

Upaya untuk menghentikan penyebaran Covid-19 ini pemerintah selalu mengingatkan masyarakat untuk menghindari keramaian, melakukan physical distancing, menggunakan masker, dan mencuci tangan. Dalam rangka melakukan physical distancing dalam dunia pendidikan maka pemerintah membuat kebijakan baru yaitu pembelajaran secara penuh dilaksanakan dirumah atau dikenal dengan pembelajaran daring atau online.

Agar pembelajaran daring dapat terlaksana seperti yang diharapkan maka diciptakan inovasi pembelajaran dengan memanfaatkan teknologi yang ada. Dalam upaya menciptakan pembelajaran daring yang efektif maka guru harus mampu menentukan pembelajaran online yang bagaimana akan ia terapkan kepada siswa. Oleh karena itu, memahami prinsip dan faktor yang mempengaruhi efektivitas teknologi digital dalam pembelajaran adalah sesuatu yang sangat penting bagi seorang pendidik [16]. Walau tidak bisa dipungkiri bahwa sekolah offline atau tatap muka memanglah jauh efektif dibandingkan belajar secara daring. Namun, hal itu tidak menjadi alasan untuk menghambat guru dan siswa secara aktif dan kreatif belajar secara daring. Meskipun pembelajaran daring masih menemukan beberapa masalah diantaranya adalah jaringan tidak lancar dan kuota internet yang memberatkan bagi siswa dan guru [17].

Guru diharapkan dapat mengikuti perkembangan dan mengerti akan teknologi yang ada saat ini, hal ini sudah digalakkan jauh 
sebelum kita mengenal Covid-19. Sesuai dengan pendapat Wulandari dikatakan bahwa guru harus mampu mengembangkan profesi dan menjalankan tugasnya dengan menyesuaikan kebutuhan siswa serta materi pembelajaran yang mengikuti perkembangan zaman [18].

Agar pembelajaran daring berjalan sesuai yang diharapkan, maka guru harus menggunakan alat bantu seperti aplikasi Whatsapp Group, Google Classroom, Google Meet dan lain sebagainya. Penggunaan internet dan teknologi multimedia mampu merombak cara penyampaian materi dan dapat menjadi alternatif pembelajaran yang dilaksanakan dalam kelas [19]. Dalam proses pembelajaran daring komunikasi yang intensif sangat dibutuhkan, baik antara guru dengan siswa, siswa dengan orang tua, maupun guru dengan orang tua untuk selalu sejalan dalam membimbing kegiatan belajar siswa di rumah [20].

Pada penelitian ini, proses pembelajaran daring memanfaatkan aplikasi Google Meet untuk menunjang pembelajaran yang efektif. Aplikasi Google Meet menjadi pilihan karena dinilai lebih efektif dalam penyampaian materi kepada siswa. Penggunaan aplikasi Google Meet pada saat pembelajaran membuat guru lebih leluasa dalam menjelaskan materi sebagaimana hampir mirip dengan situasi pembelajaran tatap muka, pada aplikasi Google Meet juga guru bisa bertatap muka dengan siswa meskipun secara virtual. Terpenting, Google Meet dapat diakses secara gratis oleh semua guru dan tidak perlu membeli akun premium seperti aplikasi berbayar lainnya.

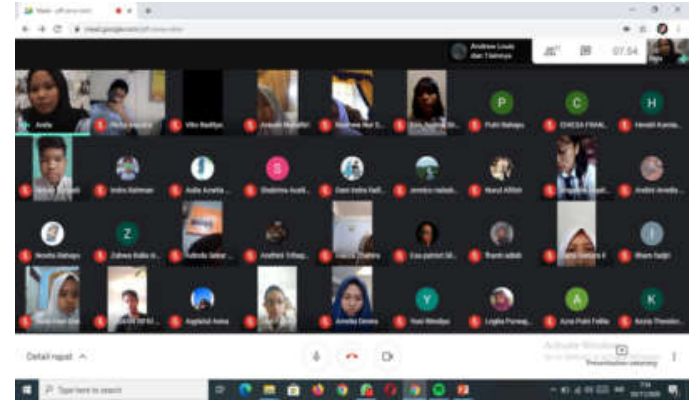

Gambar 3. Pembelajaran daring bersama kelas $\mathrm{X}$ IPS 1 SMA Negeri 3 Pekanbaru menggunakan aplikasi Google Meet.
Dalam pembelajaran daring dengan memanfaatkan aplikasi Google Meet, guru dapat melihat dan mamastikan bagaimana kesiapan serta keaktifan siswa dalam proses pembelajaran. Dengan adanya fitur on kamera maka guru dapat memmastikan bahwa siswa penuh perhatian dan siap untuk ikut berpartisipasi dalam pembelajaran. Tidak hanya itu, guru bisa lebih leluasa dalam menyampaikan materi dengan menggunakan bantuan media pembelajaran sehingga siswa masih dapat memahami materi dengan baik. Terjadi juga proses diskusi dan tanya jawab yang dilakukan antara guru dan siswa maupun antara siswa dengan siswa lainnya.

Hasil wawancara dengan guru di SMA Negeri Pekanbaru, disimpulkan bahwa aplikasi Google Meet merupakan aplikasi yang lebih efektif dibandingkan aplikasi lainnya apabila digunakan untuk pembelajaran daring di SMA Negeri 3 Pekanbaru. Aplikasi Google Meet dianggap sangat praktis dan memudahkan guru dalam menyampaikan materi. Namun, persepsi guru dan siswa terhadap penggunaan aplikasi Google Meet saat pembelajaran daring tentu tidak bisa disama ratakan. Berikut tanggapan siswa terhadap penggunaan aplikasi Google Meet dalam proses pembelajaran:

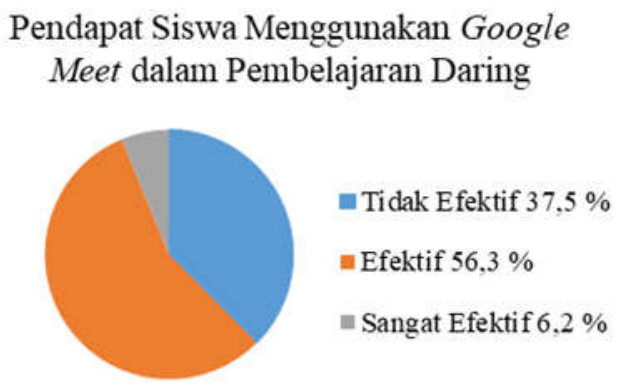

Gambar 4. Pendapat siswa kelas X IPS 1 SMA Negeri 3 Pekanbaru terhadap pembelajaran daring menggunakan aplikasi Google Meet.

Berdasarkan Gambar 4 tentang persepsi siswa terhadap pembelajaran Google Meet, menunjukkan bahwa siswa X IPS 1 SMA Negeri 3 Pekanbaru menganggap bahwa penggunaan aplikasi Google Meet saat pembelajaran daring tergolong lebih efektif dengan persentase $56,3 \%$. Menurut pendapat siswa, Google Meet tergolong efektif dikarenakan bisa langsung berkomunikasi 
dengan guru yang mengajar sehingga materi yang dijelaskan masih dapat dipahami dengan baik. Selain itu, juga dapat berdiskusi langsung dengan guru apabila terdapat hal-hal yang perlu dipertanyakan atau membutuhkan penjelasan lebih lanjut.

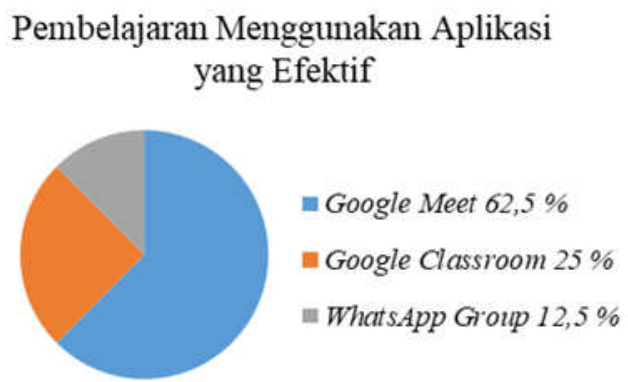

Gambar 5. Perbandingan aplikasi paling efektif saat pembelajaran daring menurut siswa X IPS 1 SMA Negeri 3 Pekanbaru

Berdasarkan Gambar 5 di atas, siswa X IPS 1 SMA Negeri 3 Pekanbaru beranggapan bahwa aplikasi paling efektif ialah aplikasi Google Meet, yakni sekitar $62,5 \%$ siswa memilih Google Meet sebagai aplikasi paling efektif, dilanjutkan dengan aplikasi Google Classroom pada posisi kedua dengan persentase sebesar $25 \%$, dan yang terakhir Whatsapp Group dengan persentase 12,5\%.

Berdasarkan analisis data di atas tentang aplikasi yang paling efektif menurut siswa saat pembelajaran daring, menunjukkan bahwa persepsi siswa dan guru mengenai aplikasi paling efektif saat pembelajaran daring adalah sama, yakni paling rekomendasi menggunakan Google Meet. Sama halnya dengan penelitian terdahulu dari Wati [21], menjelaskan bahwa pembelajaran online menggunakan Google Meet adalah solusi yang sangat efektif bagi guru untuk menghidupkan kembali proses belajar mengajar selama pandemi Covid-19.

\section{CONCLUSION}

Berdasarkan hasil penelitian yang dilakukan, penggunaan teknologi dalam pembelajaran daring sangat menunjang keefektifan belajar. Penggunaan aplikasi pembelajaran tergantung kebijakan dari guru yang mengajar dan sesuai dengan minat siswa dalam menggunakan aplikasi belajar daring. Dimana setiap aplikasi memiliki kelebihan dan kekurangan masing-masing, tetapi di SMA Negeri 3 Pekanbaru lebih cendrung menggunakan Google Meet.

Aplikasi Google Meet memiki kelebihan, yakni dapat membantu guru menjelaskan materi secara detail sehingga siswa lebih mudah memahami. Selain itu, juga dapat berdiskusi langsung dengan guru apabila terdapat hal-hal yang perlu dijelaskan lebih detail. Namun, Google Meet menuntut kestabilan jaringan internet sehingga ini menjadi tantangan yang harus diperhatikan oleh pengguna, baik guru maupun siswa.

\section{REFERENCES}

Hasan, M. (2020). Perubahan Paradigma Pendidikan dan Ekonomi Dimasa Pandemi Covid-19: Peluang, Tantangan, dan Strategi. Jawa Barat: CV. Media Sains Indonesia.

Anugrahana, A. (2020). Hambatan, Solusi dan Harapan: Pembelajaran Daring Selama Masa Pandemi Covid-19 Oleh Guru Sekolah Dasar. Scholaria: Jurnal Pendidikan dan Kebudayaan, 10(3), 282289.

https://doi.org/10.24246/j.js.2020.v10.i3. p282-289

Rustaman, A. H. (2020). Efektivitas Penggunaan Aplikasi Daring, Video Conference Dan Sosial Media Pada Mata Kuliah Komputer Grafis 1 Di Masa Pandemi Covid-19. Jurnal Ilmu Sosial dan Pendidikan, 4(3), 557-562. http://dx.doi.org/10.36312/jisip.v4i3.127 4

Pujiasih, E. (2020). Membangun Generasi Emas dengan Variasi Pembelajaran Online di Masa Pandemi Covid-19. Ideguru: Jurnal Karya Ilmiah Guru, 5(1), 42-48.

Sawitri, D. (2020). Penggunaan Google Meet Untuk Work From Home Di Era Pandemi Coronavirus Disease 2019 (Covid-19). Jurnal Prioritas: Jurnal Pengabdian Masyarakat, 2(1), 13-21. Available at: http://jurnal.harapan.ac.id/index.php/Prio ritas/article/view/161 
Irmawanty., Sumantri, M. S., \& Japar, M. (2020). Pendampingan Menulis Karya Tulis Ilmiah (KTI) Pada Guru Madrasah Ibtidaiyah Secara Online dengan Menggunakan Google Meet. Prosiding Seminar Nasional Pascasarjana Universitas Negeri Jakarta, 26 Agustus, 146-53.

Nalurita, S. (2021). Pemanfaatan Aplikasi Google Meet Pada Mata Kuliah Teknik Proyeksi Bisnis Semester Gasal Tahun Pelajaran 2020/2021 di Universitas Dirgantara Marsekal Suryadarma (Unsurya) (Studi pada Mahasiswa Prodi Manajemen Kelas G). Jurnal Ilmiah Manajemen Surya Pasca Scientia, 10(1), 22-30.

Abidin, Z., Hudaya, A., \& Anjani, D. (2020). Efektivitas Pembelajaran Jarak Jauh Pada Masa Pandemi Covid-19. Reseacrh and Development Journal of Education (Special Edition), 131-146. http://dx.doi.org/10.30998/rdje.v1i1.7659

Nuriansyah, F. (2020). Efektifitas Penggunaan Media Online Dalam Meningkatkan Hasil Belajar Pada Mahasiswa Pendidikan Ekonomi Saat Awal Pandemi Covid-19. Jurnal Pendididikan Ekonomi Indonesia, 1(2), 61-65.

Irmawanty., Sumantri, M. S., \& Japar, M. (2020). Pendampingan Menulis Karya Tulis Ilmiah (KTI) Pada Guru Madrasah Ibtidaiyah Secara Online dengan Menggunakan Google Meet. Prosiding Seminar Nasional Pascasarjana Universitas Negeri Jakarta, 26 Agustus, 146-53.

Rustaman, A. H. (2020). Efektivitas Penggunaan Aplikasi Daring, Video Conference Dan Sosial Media Pada Mata Kuliah Komputer Grafis 1 Di Masa Pandemi Covid-19. Jurnal Ilmu Sosial dan Pendidikan, 4(3), 557-562. http://dx.doi.org/10.36312/jisip.v4i3.127 4

Sayidah, N. (2018). Metodologi Penelitian Disertai Dengan Contoh Penerapannya Dalam Penelitian. Sidoarjo: Zifatama Jawara.
Sugiyono. (2017). Metode Penelitian Kualitatif: Untuk Penelitian yang Bersifat: Eksploratif, Enterpretif, Interaktif, dan Konstruktif. Bandung: Alfabeta.

Manab, A. (2017). Menggagas Penelitian Pendidikan: Pendekatan Studi Kasus. Yogyakata: Kalimedia.

Arikunto, S. (2002). Prosedur Penelitian Suatu Pendekatan Praktek. Jakarta: Asdi Mahasatya.

Putrawangsa, S., \& Hasanah, U. (2018). Integrasi Teknologi Digital dalam Pembelajaran di Era Industri 4.0. Jurnal Tatsfiq, 16(1), 42-54. https://doi.org/10.20414/jtq.v16i1.203

Absor, N. F. (2020). Pembelajaran Sejarah Abad 21: Tantangan dan Peluang dalam Menghadapi Pandemi Covid-19. Choronologia: Journal of History Education, 2(1), 30-35. http://dx.doi.org/10.22236/jhe.v2i1.5502

Wulandari, S. S. (2018). Peningkatan Kompetensi Profesional Guru Kewirausahaan Melalui Lesson Study Berbasis Pantai dan Laut. JPE (Jurnal Pendidikan Edutama), 5(2), 69-78. http://dx.doi.org/10.30734/jpe.v5i2.193

Handarini, O. I., \& Wulandari, S. S. (2020). Pembelajaran Daring Sebagai Upaya Study From Home (SFH) Selama Pandemi Covid-19. Jurnal Pendidikan Administrasi Perkantoran (JPAP), 8(3), 496-503.

Astuti, A. D., \& Prestiadi, D. (2020). Efektivitas Penggunaan Media Belajar Dengan Sistem Daring Ditengah Pandemi Covid-19. Prosiding WebSeminar Nasional (Webinar), 20 Juni, 129-135.

Wati, N. M. W. (2020). Efektivitas Pembelajaran Menggunakan Aplikasi Google Meet Pada Anak SMA di Masa Pandemi Covid-19. Cetta: Jurnal Ilmu Pendidikan, 3(3a-1). Retrieved from http://jayapanguspress.penerbit.org/index .php/cetta/article/view/991 